\title{
Recommended conservation of the names Streptococcus sanguis, Streptococcus rattus, Streptococcus cricetus, and seven other names included in the Approved Lists of Bacterial Names. Request for an Opinion
}

M. Kilian

Fax: +45 8619 6128. e-mail: kilian@microbiology.au.dk

Department of Medical Microbiology and Immunology, University of Aarhus, The Bartholin Building, DK-8000 Aarhus C, Denmark

\begin{abstract}
With reference to the first Principle of the International Code of Nomenclature of Bacteria, which emphasizes stability of names, it is proposed that the original names Streptococcus sanguis, Streptococcus rattus, Streptococcus cricetus, Erwinia ananas, Eubacterium tarantellus, Lactobacillus sake, Nitrosococcus oceanus, Pseudomonas betle, Rickettsia canada and Streptomyces rangoon, all included in the Approved Lists of Bacterial Names, be conserved. Request for an Opinion.
\end{abstract}

Keywords: Bacteriological Code, nomenclature
In a Taxonomic Note, Trüper \& de' Clari (1997) draw attention to Rule $12 \mathrm{c}$ of the International Code of Nomenclature of Bacteria (Lapage et al., 1992) which states that a specific epithet must be treated in one of the following ways: (i) as an adjective that must agree in gender with the generic name; (ii) as a substantive (noun) in apposition in the nominative case, or (iii) as a substantive (noun) in the genitive case. Trüper \& de' Clari correctly state that several examples of bacterial names demonstrate that the formation of epithets as substantives in apposition (option ii) sometimes has been misunderstood. The authors provide a helpful explanation to the relevant grammatical rules. These rules are further explained in a response (de' Clari, 1999) to my letter published in $A S M$ News (Kilian, 1998).

With reference to Rule 12c, Trüper \& de' Clari (1997) included a list of bacterial names that require 'necessary correction'. Along with 20 other species, this list included the names of four Streptococcus species: Streptococcus sanguis, Streptococcus crista, Streptococcus parasanguis and Streptococcus rattus, for which the grammatically correct forms are 'Streptococcus sanguinis', 'Streptococcus cristatus', 'Streptococcus parasanguinis' and 'Streptococcus ratti'. In a subsequent note, Trüper \& de' Clari (1998) corrected one of their corrections and listed an additional ten epithets of bacterial names that are grammatically incorrect. This list included Streptococcus cricetus which, according to Trüper \& de' Clari, should be corrected to 'Streptococcus criceti'.

Although there is provision under Rule 61 for correcting typographic or orthographic errors in epithets, the note to Rule 61 states that the liberty to correct a name or epithet must be used with reserve. Emphasis on this reservation is in accordance with the very first of the 'essential points of nomenclature' stated as Principle 1 of the Code, i.e. to 'aim at stability of names'. Euzéby (1998), in his subsequent Note, lists many important arguments for giving highest priority to that principle unless typographic or orthographic errors are discovered within a reasonable time after the proposal of a new name. He furthermore proposed that Rule 61 of the Code be amended to avoid changes of names or epithets that were included in the Approved Lists of Bacterial Names (Skerman et al., 1980). Among the names corrected by Trüper \& de' Clari, the following are included in the Approved Lists: Streptococcus sanguis White and Niven 1946, Streptococcus rattus Coykendall 1977 and Streptococcus cricetus Coykendall 1977 in addition to names of seven species belonging to other genera, Erwinia ananas Serrano 1928, Eubacterium tarantellus Udey et al. 1977, Lactobacillus sake Katagiri et al. 1934, Nitrosococcus oceanus (Watson 1965) Watson 1971, Pseudomonas betle (Ragunathan 1928) Savulescu 1947, Richettsia canada McKiel et al. 1967 and Streptomyces rangoon (Erikson 1935) Pridham et al. 1958. These names have all been in use for over 30 
years and are well-established in the bacteriological literature and in various databases. So are many of the other names in the lists published by Trüper \& de' Clari (1997, 1998).

I agree that utmost care should be employed by authors and editors to ensure that new names published in the International Journal of Systematic and Evolutionary Microbiology, in original articles or in the Validation Lists, are formally correct. Preferably, correction of errors in bacterial names should be restricted to the period of time between their original publication and their inclusion in the Notification or Validation Lists published in the International Journal of Systematic and Evolutionary Microbiology. This could logically be the responsibility of the editorial team or the relevant taxonomic subcommittees. Introduction of new taxa or names should never become a trivial matter.

The changing of well-established names of species of Streptococcus and other genera is not desirable as it will cause unnecessary confusion and frustration among those who use these names in their daily work. It will render searches in databases more complicated, and taxonomists and taxonomy in general will be unduly discredited. I therefore recommend that the original names Streptococcus sanguis, Streptococcus rattus and Streptococcus cricetus, along with seven other bacterial names included in the Approved Lists of Bacterial Names (Skerman et al., 1980) be con- served. What can be gained by conserving these wellestablished, though grammatically incorrect spellings? Stability of names in accordance with Principle 1 of the International Code, and first and foremost, retention of the ability to communicate and search databases in an unequivocal way.

\section{References}

de' Clari, L. (1999). Did we demonstrate a lack of respect in correcting a bacteriological misnomer? ASM News 65, 522.

Euzéby, J. P. (1998). Proposal to amend Rule 61 of the International Code of Nomenclature of Bacteria (1990 revision). Int J Syst Bacteriol 48, 611-612.

Lapage, S. P., Sneath, P. H. A., Lessel, E. F., Skerman, V. B. D., Seeliger, H. P. R. \& Clark, W. A. (editors) (1992). International Code of Nomenclature of Bacteria (1990 Revision). Bacteriological Code. Washington, DC: American Society for Microbiology.

Kilian, M. (1998). Necessary changes of bacterial names? ASM News 64, 670.

Skerman, V. B. D., McGowan, V. \& Sneath, P. H. A. (editors) (1980). Approved lists of bacterial names. Int J Syst Bacteriol 30, 225-420.

Trüper, H. G. \& de' Clari, L. (1997). Taxonomic note: necessary correction of specific epithets formed as substantives (nouns) “in apposition". Int J Syst Bacteriol 47, 908-909.

Trüper, H. G. \& de' Clari, L. (1998). Taxonomic note: erratum and correction of further specific epithets formed as substantives (nouns) ‘in apposition'. Int J Syst Bacteriol 48, 615. 